\title{
Unprepared for the single market
}

Will it be different after 1992? The general expectation that everything in Europe will change when the EEC (at last) becomes a common market is belied by the inadequacy of the preparation for that event.

THE EEC's research programme, the subject of the last part of this survey of European science, has always been controversial and will long remain so. The Treaty of Rome omitted to give the European Commission the power to sponsor research, because in the simple customs union then foreseen, the Commission needed merely the power to create the level playing-field on which companies in member states could compete on equal terms. In the 1950 s, before research became a self-conscious component of public policy and long before governments recognized the link between research and prosperity, research belonged with cultural policy squarely within the competence of member states. Both the Iron and Steel Community and Euratom (which predated EEC) had research remits, but they had technical needs to satisfy.

Since then, the Commission has stumbled into research by historical accident - the coincidence of its administrative takeover of the two subsidiary communities with the rise of European anxieties in the 1970s about the 'technology gap' between Europe and the rest of the industrialized world. The Commission has responded manfully, but not always wisely, to this challenge. Its programmes described in the preceding pages are merely the most conspicuous. Yet now, with the prospect of a single market going beyond a mere customs union, there can be no doubt that the Commission has a proper role in research. The Single Act that promises great things for 1992 acknowledges as much. The danger now is that what it does will be the extrapolation into the future of present historical accidents. Several questions arise.

First, there is the matter of administration. In part, the Commission has been unfairly pilloried. The Joint Research Centre (once named in the plural) was in a bad way when the Commission took it over. Now, at least, there is a workable structure and a plan that may succeed (page 732). It should be given a fair chance. The more expensive cost-sharing programmes (page 729) are a more mixed bag. Much of the work they support is valuable - the evaluation panels say so - but they would be more valuable if they were not so often hastily thrown together. Often the Commission will spend well over a year winning approval for some scheme, give client companies and academics a few months in which to apply - and then spend more than a year making legal arrangements for the funds to be released.

Second, there is the matter of what the Commission's research is for. As stated, the purpose is to enhance industrial "competitiveness" while supporting only "precompetitive" industrial research. The Farge panel last year spotted that contradiction. Another, certain to seem sharper after 1992, is whether it will make sense to insist that industrial research projects qualifying for assistance should always entail transnational collaboration when European competitiveness (with the outside world) could be based on a single efficient company. A further difficulty is that these projects seem to concentrate on innovation (often the 'me-too' kind) rather than efficiency, suggesting that self-sufficiency is the real goal.

Third, there is the matter of the balance between basic and applied research. The Commission has so far concentrated on the second, but acknowledges that Europe's future hangs not only on a torrent of innovation but on a sufficient supply of innovative people. The logic of that is that it should be spending a greater proportion of its funds on basic research, which is the only proven way of systematically turning talented people into innovators. The SCIENCE programme (page 734) is fine, but should be increased and also supplemented by a means of backing long-term institutional endeavours. The planned, but frustrated, VLBI scheme (page 719) is a test-case.

Fourth, there is the matter of the Commission's own dependence on science. Even among its constituents, the Commission has a bad name for making technical decisions in apparent ignorance of the ins and outs of technical questions. The decision last year to ban the use of anabolic steroids in growing beef followed the over-stringent standards for radioactive materials in food adopted in the aftermath of Chernobyl two years ago. But the Commission corporately is not nearly as ignorant as it makes itself seem. It is merely that when technicalities contradict what seem to be political, social or economic imperatives, it is easier to make a decision by neglecting to ask for the inconvenient advice. That may keep member-governments happy, but it is not a way to govern.

Finally, there is the related matter of the Commission's own personnel, researchers on its payroll, for example. As things are, the Commission is compelled by its member governments to operate a quota system: governments do not want to stuff ECUs into other nationals' pockets, especially in such large amounts. Will petty chauvinism of that kind make sense after 1992? And if not, how else are talented people to be employed? The question is again administrative, but it also goes deeper: the Commission expects 1992 to be a milestone on the way to a United States of Europe. If it had its time again, the Commission would no doubt start from somewhere other than the Treaty of Rome, perhaps from a common understanding on external relations. But history does not repeat itself for the benefit of those whom it inconveniences. The Commission's flair for dealing with its officials as if they were European could be another acid test of the validity of its ambitions for Europe. 